\title{
A fruit wing of Shorea Roxb. from the Early Miocene sediments of Kachchh, Gujarat and its bearing on palaeoclimatic interpretation
}

\author{
Anumeha Shukla*, J S Guleria and R C Mehrotra \\ Birbal Sahni Institute of Palaeobotany, 53 University Road, Lucknow 226 007, India. \\ *Corresponding author.e-mail: anu_bsip@yahoo.co.in
}

\begin{abstract}
A new fossil fruit wing of Shorea Roxb. belonging to the family Dipterocarpaceae is described from the Early Miocene sediments of Kachchh, Gujarat. It resembles best the extant species Shorea macroptera Dyer, which is a prominent member of the tropical evergreen forests of the Malayan Peninsula. The present finding, along with the other megafossil records described from the same area, indicates a typical tropical vegetation with a warm and humid climate at the time of deposition in contrast to the present day xeric vegetation in the area. As the family Dipterocarpaceae no longer exists in western India, it is essential to discuss the time of its extinction and possible causes, which may include drastic changes in the climate of the region. The present finding also supports the theory of a Malaysian origin for the family in contrast to the hypothesis of a Gondwanan origin.
\end{abstract}

\section{Introduction}

Phytogeographically, the family Dipterocarpaceae is one of the most important angiosperm components of tropical evergreen forests in the IndoMalayan region. It is said to have entered in India through the north-east, sometimes during the Late Oligocene-Early Miocene when land connections between India and Myanmar were well established and the Tethys Sea in the Himalayan fore-deep had completely vanished (Lakhanpal 1970; Smith et al 1994). Throughout the Neogene, the family was a common element of tropical vegetation on the Indian peninsula (Lakhanpal 1970; Guleria 1992) but after the Pliocene it disappeared from most parts of India and became restricted to the evergreen forest of Assam, Western Ghats and Andamans (Chowdhury and Ghosh 1958; Santapau and Henry 1973).
At present, most of the dipterocarps occur in evergreen and well-drained tropical rain forests of the Indo-Malayan region (Pearson and Brown 1932; Foxworthy 1946; Willis 1973; Ashton 1982, 2003). Most of them are equipped with wings which aid in the dispersal of fruit by wind. Out of 563 species of dipterocarps, only 29 species representing 6 genera are found in India (including Andaman Island) and Bangladesh (Willis 1973; Pearson and Brown 1932; Mabberley 1997). Shorea Roxb., the largest genus of the family comprising about 196 species, belongs to the Dipterocarpoideae, one of the three subfamilies of Dipterocarpaceae. Almost all the species of this genus are rainforest trees and native to southeast Asia ranging from northern India to Malaysia, Indonesia and Philippines (Pearson and Brown 1932).

The fossil being described here was collected from the twin villages, Goyela-Mokra, situated

Keywords. Shorea; Early Miocene; fruit wing; palaeoclimate; Dipterocarpaceae; Kachchh; India. 


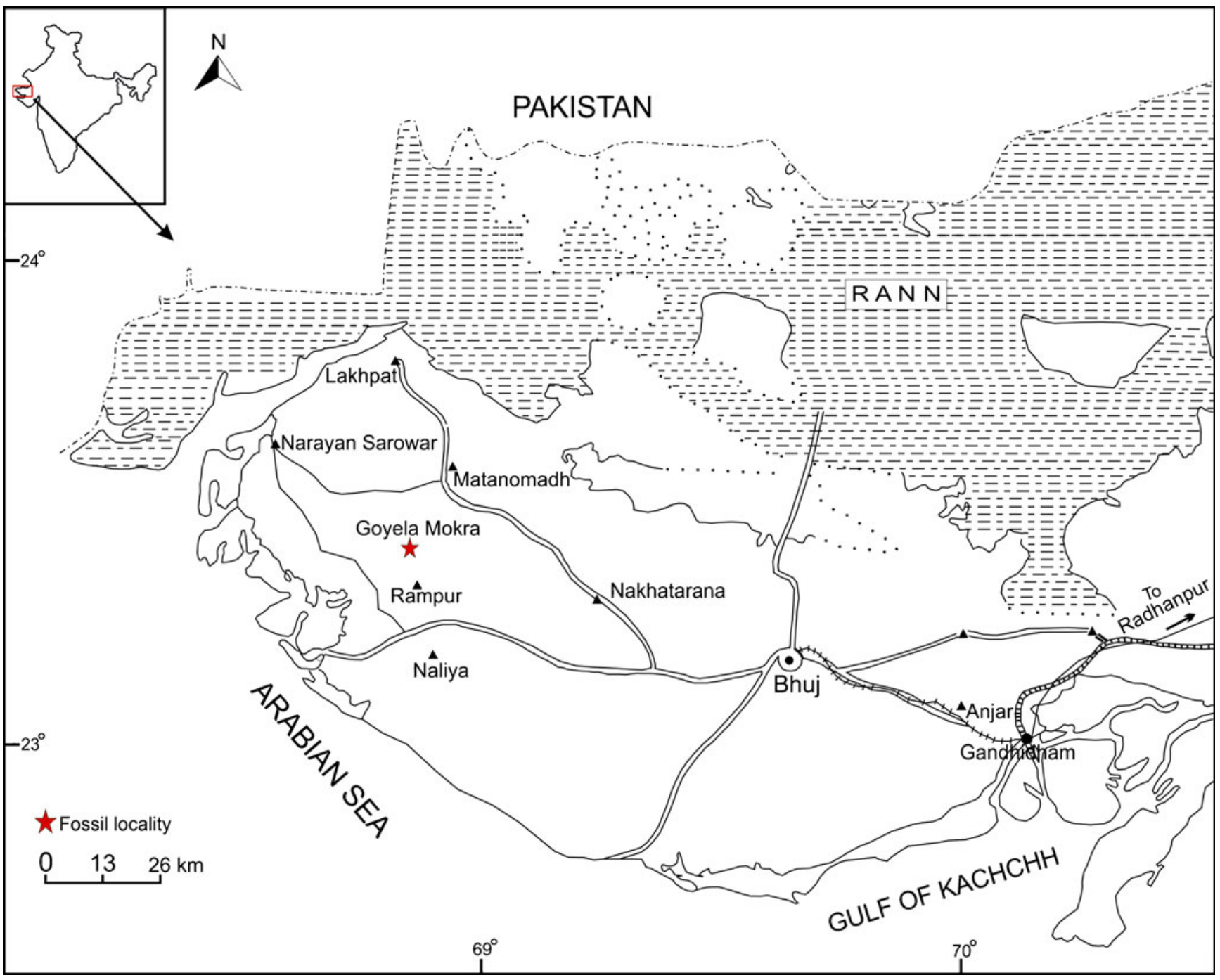

Figure 1. Map of Kachchh district showing the fossil locality.

Table 1. Previously recorded plant megafossils from the Khari River Formation, Kachchh.

\begin{tabular}{llc}
\hline Fossil species & \multicolumn{1}{c}{ Modern counterparts } & References \\
\hline Arecaceae & & Lakhanpal and Guleria (1982) \\
Plamacites khariensis & Terminalia chebula & Lakhanpal et al (1984) \\
Combretaceae & & Lakhanpal and Guleria (1982) \\
Terminalia kachchhensis & Bauhinia phoenicea, B. purpurea & -do- \\
Fabaceae & Cassia sp. & -do- \\
Bauhinia kachchhensis & Ficus infectoria & -do- \\
Cassia miokachchhensis & Fruit cf. Fabaceae & -do- \\
Ficus khariensis & Leaf cf. Fabaceae & -do- \\
Leguminocarpon khariensis & Seed cf. Fabaceae & -do- \\
Leguminophyllum khariensis & M. auriculata & Lakhanpal and Guleria (1982) \\
Leguminosites khariensis & & Lakhanpal et al (1984) \\
Millettia miocenica & Cinnamomum zeylanicum & Lakhanpal and Guleria (1982) \\
Cinnamomum miokachchhensis & & \\
Rhizophoraceae & Ceriops decandra, C. tagal & \\
Ceriops kachchhensis & Murraya paniculata & \\
Rutaceae & &
\end{tabular}


west of Bhuj and north of Naliya. The fossil site $\left(23^{\circ} 25^{\prime} \mathrm{N}, 68^{\circ} 52^{\prime} \mathrm{E}\right)$ lies about $2.5 \mathrm{~km}$ south of Goyela-Mokra on the southern bank of the Khari Nadi river and is about $100 \mathrm{~m}$ east of the road where it cuts the channel (figure 1) and was derived from the Khari Nadi Formation of the Kachchh Basin, Gujarat. This formation consists of mainly laminated, very thin-bedded, red and yellow mottled to variegated siltstone and occasionally grey and brown gypsum claystone. A bluish grey claystone bed occurs consistently near the base in every section. The environment of deposition of this formation varies from tidal flat to littoral and shallow marine environment of a slowly trangressive sea (Biswas and Raju 1973). The fossil wing has been found in the lower $15.2 \mathrm{~m}$ of the section associated with blue clay. The formation ranges in age from the uppermost Oligocene (Chattian) to lowermost Miocene (Aquitanian) (Biswas and Raju 1973). A number of megafossils already described from Khari Nadi Formation are enlisted in table 1.

\section{Materials and methods}

The fossil specimen is the form of an impression which is well preserved. It has been cleaned with the help of a chisel and hammer and photographed under the reflected light using Canon SX 100 digital camera. The morphological details of the fruit wings of Dipterocarpaceae have been thoroughly discussed by Aston $(1982,2003)$. In this paper, the terms to describe the fruit wing and its venation are based on standard terminology for the description of dicot leaves (Hickey 1973, 1979; Dilcher 1974; Leaf Architecture Working Group 1999). The type specimen is housed in the museum of the Birbal Sahni Institute of Palaeobotany, Lucknow.

\section{Systematic description}

Order: Malvales Dumort

Family: Dipterocarpaceaec Blume

Genus: Shorea Roxb.

Species: Shorea kachchhensis, Shukla, Guleria and Mehrotra, sp. nov.

Description: The fossil is a single calyx 'lobe' of a fruit wing with its attachment, the depression part of the wing indicating its attachment to the fruit. Lobe symmetrical, linear lanceolate, $5.83 \times$ $1.48 \mathrm{~cm}$ in size, apex obtuse, base seemingly narrow, margin entire, 10-11 primary veins running parallel to the length of the wing; transverse veins joining the longitudinal veins at an angle of $70^{\circ}-80^{\circ}$ (sometimes at right angles), showing oblique pattern, tertiaries not seen.

Holotype: Specimen no. BSIP 39900.

Horizon: Khari Nadi Formation.

Locality: Goyela-Mokra village, district Kachchh, Gujarat.

Age: Early Miocene.

Material: One well preserved specimen.

Etymology: After Kachchh from where the fossil is described.

\section{Comparison and discussion}

The characteristic features of the present fossil are: a linear lanceolate shape, 10-11 parallel primary veins connecting to each other with small transverse veins and a groove or attachment depression at the base. All these characters show its strong affinities with the fruiting calyx of the family Dipterocarpaceae. With the help of herbarium sheets available at the Central National Herbarium, Howrah and the Forest Research Institute, Dehradun, the fossil was compared with various genera of the family, viz., Anisoptera Korth., Dipterocarpus Gaerth., Hopea Roxb. and Shorea Roxb (=Parashorea Kurz). The closest resemblance is to fruit wing of the extant genus Shorea Roxb (Ridley 1922). The other genera (i.e., Anisoptera, Dipterocarpus and Hopea) are dissimilar in having fewer longitudinal nerves and in the attachment pattern between the two adjoining nerves. The number of primary veins in all the extant genera except for Shorea are no more than 5 or 6 in contrast to 10-11 in the fossil. For further identification, fruit wings of many Shorea species were thoroughly examined and S. parvifolia Roxb. and S. macroptera Dyer were found to show the most resemblance to the fossil. However, S. parvifolia also differs from the fossil in having only eight primary veins. The fossil exhibits the closest resemblance to the fruit wing of $S$. macroptera (Herbarium Sheet No. CNH 51590 , figure $2 \mathrm{~b}, \mathrm{e})$. The modern analogue of the fossil is $50-80 \mathrm{~m}$ tall and mainly distributed in the rainforests of the Malayan peninsula.

Fossil fruit wings belonging to the family Dipterocarpaceae are known from various Neogene localities within India and China. The first fruit wing resembling Anisoptera Korth. was described by Prasad (2006) from the Miocene sediments of Himachal Pradesh. Thereafter, another wing belonging to Shorea Roxb. was described by Khan and Bera (2010) from the Middle-Upper Miocene of Arunachal Pradesh. Shi and Li (2010) also described a dipterocarp fossil wing from the Middle Miocene of China. The present fossil was compared with all the described fruit wings and was found to 

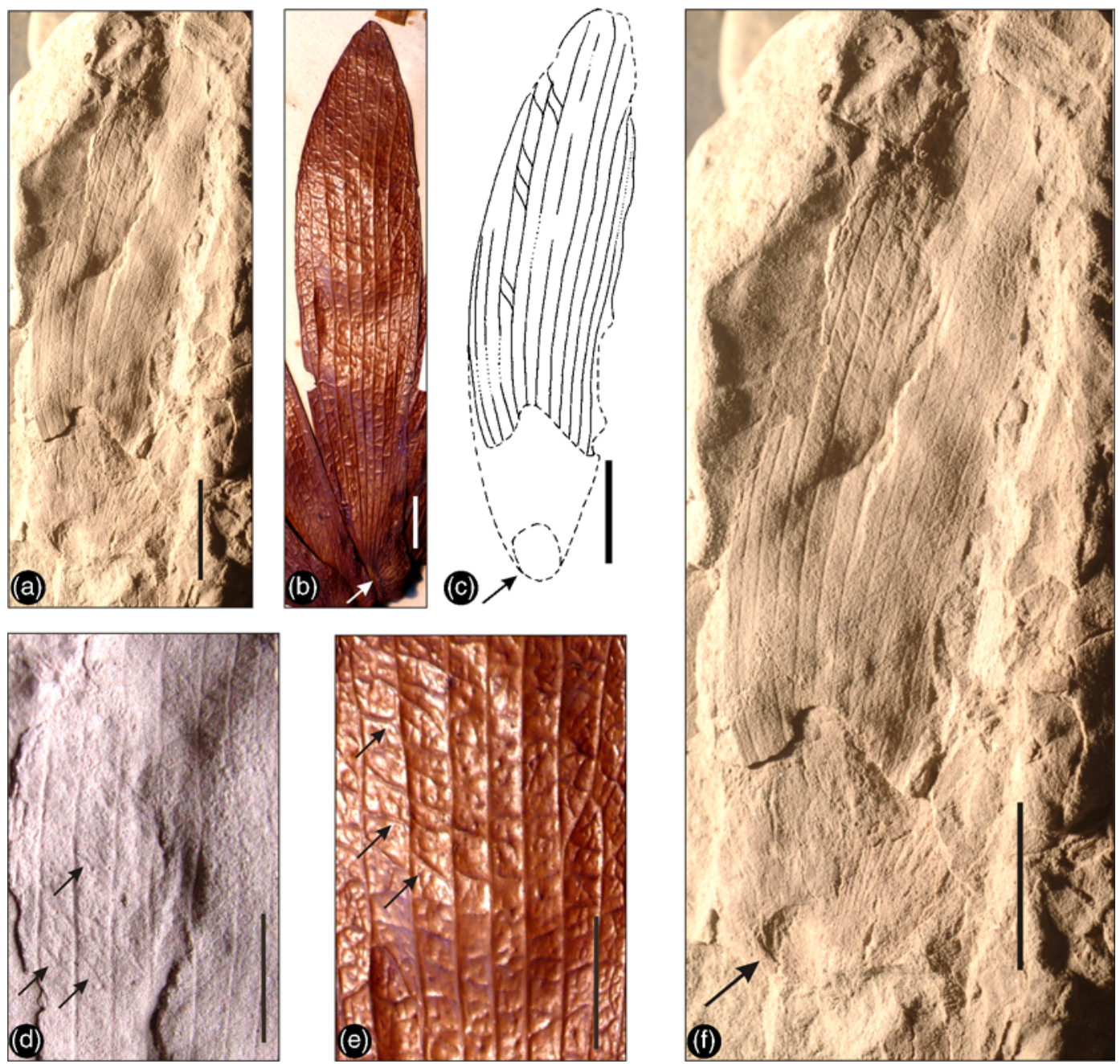

Figure 2. (a) Fossil fruit wing of Shorea kachchhensis sp. nov. showing shape, size and venation pattern; (b) fruit wing of extant species, Shorea macroptera Dyer showing similar shape, size and venation pattern (arrow indicating depression in the wing showing its attachment with the fruit); (c) text diagram of fruit wing of S. kachchhensis sp. nov.; (d) enlarged figure showing transverse veins (secondaries) of the fossil (arrows indicating transverse veins); (e) showing similar transverse veins in $S$. macroptera Dyer as found in the fossil; and (f) enlarged figure of the fossil to show parallel venation and the attachment of fruit (marked by arrow) (Bar scale $=1 \mathrm{~cm})$.

be different in having more primary veins (table 2). Since the present fruit wing differs from the known fossil records, it is assigned to a new species of
Shorea, i.e., Shorea kachchhensis sp. nov., the specific epithet indicating its occurrence in the Kachchh district.

Table 2. List of known fossil fruit wings of the family Dipterocarpaceae showing their main morphological characters.

\begin{tabular}{|c|c|c|c|c|c|c|}
\hline Fossil species & $\begin{array}{l}\text { Primary } \\
\text { veins }\end{array}$ & Shape & Apex & Base & $\begin{array}{l}\text { Length/width } \\
\text { ratio (in } \mathrm{cm} \text { ) }\end{array}$ & $\begin{array}{c}\text { Nature of } \\
\text { transverse veins }\end{array}$ \\
\hline $\begin{array}{l}\text { Anisoptera miocurtisii, } \\
\text { Prasad (1996) }\end{array}$ & 3 & $\begin{array}{c}\text { Linear } \\
\text { lanceolate }\end{array}$ & Broken & Broken & $6.2 / 1$ & At right angle \\
\hline $\begin{array}{l}\text { Shorea mioassamica } \\
\text { Khan and Bera (2010) }\end{array}$ & 7 & $\begin{array}{c}\text { Linear } \\
\text { lanceolate }\end{array}$ & Broken & Seemingly obtuse & $3.2 / 1.2$ & At right angle \\
\hline $\begin{array}{l}\text { Dipterocarpus zhengae } \\
\text { Shi and Li (2010) }\end{array}$ & 3 & Oblanceolate & Round-obtuse & Constricted & $13.3 / 2.2$ & At right angle \\
\hline $\begin{array}{l}\text { Shorea kachchhensis } \\
\text { sp. nov. }\end{array}$ & $10-11$ & $\begin{array}{c}\text { Linear } \\
\text { lanceolate }\end{array}$ & Obtuse & Seemingly narrow & $5.83 / 1.48$ & $70^{\circ}-80^{\circ}$ \\
\hline
\end{tabular}




\section{Palaeoclimate vs. modern climate}

Climate perhaps plays the most significant role in characterizing the environment of a particular region. Plants are largely dependant on the environment and their distribution is primarily controlled by climatic conditions. Hence, they have a 'special relationship' with climate that gives them particular value as palaeoclimate indicators. The environmental conditions under which the fossil plants lived, are often interpreted from the habitats of their modern comparable species. To understand the climatic history of the study area, the technique which is adopted here is NLR (nearest living relative). It is based on the premise that the climatic tolerances of the fossils are very similar to those of their NLRs.

By examining the present distribution of the various species of Shorea and the climatic requirements possessed by them, the climatic conditions in and around the fossil locality can be reconstructed. At present, the study area falls within the arid to semi-arid climatic zone having annual rainfall of about 20-40 $\mathrm{cm}$. A modern analogue of the fossil, Shorea macroptera Dyer, is mainly distributed in rainforests of Penang, Pahang and Perak of Malayan peninsula growing in tropical climate with abundant rainfall (more than $2000 \mathrm{~mm} /$ year). The Malayan peninsula enjoys a tropical (or equatorial) climate with warm wet weather throughout the year. Temperature is equable and ranges from $21^{\circ} \mathrm{C}$ to $32^{\circ} \mathrm{C}$, while annual rainfall varies from 2000 to $2500 \mathrm{~mm}$ (Malaysian Meteorological Department 1969-2007, http://www.met.gov.my/ index.php). This suggests that a tropical warm and humid climate prevailed in Kachchh during the
Early Miocene in contrast to the dry climate prevailing at present. This view is further substantiated by the records of previously described fossils from the same area (table 1 ). The modern counterparts of the described fossils largely belong to the evergreen to deciduous types of forest (Champion and Seth 1968) (figure 3). Therefore, the Miocene flora of Kachchh can be placed in the category of 'semi-evergreen to deciduous forest'. The result is corroborated by the occurrence of gypsum in the sediments. Gypsum is an evaporate and can only form when evaporation exceeds precipitation and thus suggesting periodically dry climate.

The total extinction of the family Dipterocarpaceae from the study area signifies drastic changes in the climate. The gradual increase in aridity during post-Pliocene rendered the environment hostile for the growth of moisture-loving plants like dipterocarps and consequently they died out in the area. The Himalayas were not as high during Early Miocene as they are today. They were uplifted in three phases (Mehrotra et al 2005), the last phase was during the Pleistocene which has increased the height of Himalayas by at least 1500$1800 \mathrm{~m}$. The cumulative effect of various factors such as change in the latitudinal position of the Indian subcontinent causing changes in the intensity and path of monsoon air-flows and further subduction of the Indian Plate against the Asian Plate accompanied with tectonic upheaval possibly led to the changes in climatic conditions from warm and humid to dry and desertic. This in turn adversely affected the past vegetation of the region. The aridity seen in eastern Africa and Arabia, coinciding with the uplift of the Himalaya, might have advanced into western India causing progressive

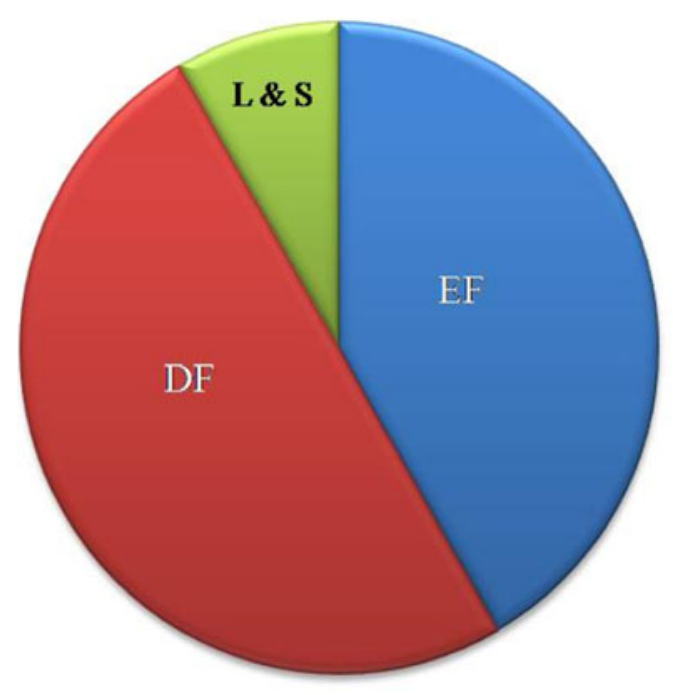

$\square$ Evergreen Forest (EF)

$\square$ Deciduous Forest (DF)

$\square$ Littoral \& Swampy Forest

(LS)

Figure 3. Pie diagram showing the distribution of various types of forest during the Early Miocene in western India. 
withdrawal of tropical wet evergreen forests from Kachchh, Gujarat (Awasthi 1994).

\section{Origin and evolution of Dipterocapaceae in India}

Two hypotheses have been postulated to explain the origin and phytogeography of Dipterocarpaceae. According to one school of thought, the family originated in southeast Asia during the late Mesozoic time (Lakhanpal 1974; Sasaki 2006), while according to the other school it had Gondwanan origin (Bossuyt and Milinkovitch 2001; Conti et al 2002; Rutschmann et al 2004). The former hypothesis was based on fossil records and modern species diversity. The latter assumes the family reached Asia rafting on the moving Indian Plate. Since we do not have any convincing record of the family from the Indian Palaeogene (Bande 1992; Mehrotra 2003), we discard this theory. After the complete joining of the Indian and Eurasian plates at the beginning of the Early Miocene, the family migrated to India from southeast Asia via Myanmar (Srivastava and Mehrotra 2010). The oldest record of the family in India is from the Early Miocene sediments of Kasauli, Himachal Pradesh (Guleria et al 2000). Following that the family became widespread in peninsular India as well as in the Himalayan foothills (Awasthi 1992; Guleria 1992; Srivastava and Mehrotra 2010). However, Dutta et al (2011) recently reported some evidence based on chemical as well as palynological analysis suggesting the presence of the family in western India during the Early Eocene. Shi and Li (2010) discarded the first hypothesis proposed by Lakhanpal (1970) and opined that "it is inconceivable that the family spread to Africa via the desert areas of the Middle East during Neogene". The question arises whether the Far East areas were really dry during the Neogene. The present finding from the desert area of western India during the Miocene suggests that it was indeed far wetter than now. We believe that the family spread to Africa via the desert area of the Middle East which might not have been desert during the Neogene. However, more study is needed to confirm this fact. Aridity must have set in towards the close of the Neogene, resulting in the complete eradication of Dipterocarpaceae from northeastern Africa and northwestern India today (Lakhanpal 1970).

The fossil records of various genera of Dipterocarpaceae, viz., Dipterocarpus, Hopea, Shorea, Dryobalanops Gaerth., Vateria L., etc., have been enlisted by Awasthi (1992) and Guleria (1992) from several Neogene localities of India. These fossil records indicate that during the Middle Miocene, the Dipterocarpaceae became one of the most dominant families in the Indian subcontinent as far as the floral diversity is concerned. After having reached its peak during the Mio-Pliocene, the family suffered a drastic decline both numerically and phytogeographically towards the close of Pliocene and beginning of Pleistocene. It faced total extinction from western India (Rajasthan and Gujarat) and eastern coast of south India by the beginning of Pleistocene. The widespread distribution of the Dipterocarpaceae clearly indicates a more or less uniform tropical climate with higher amounts of annual rainfall existed throughout the Indian peninsula during Middle Miocene-Pliocene (Awasthi 1994).

\section{Acknowledgements}

The authors are thankful to Dr N C Mehrotra, Director, Birbal Sahni Institute of Palaeobotany, Lucknow for constant encouragement as well as providing infrastructure facilities and permission to publish this work. They are grateful to Prof. R A Spicer for his helpful suggestions which helped a lot in improving the paper. Thanks are also due to Mr. Gopal Krishna (Central National Herbarium, Howrah) for his help during the photography of modern counterpart of the fossil.

\section{References}

Ashton P S 1982 Dipterocarpaceae; In: Flora Malesiana Series 1 (ed.) Van Steenis C G G J (Hague: MartinusNijhoff Publications), Spermatophyta $9237-552$.

Ashton P S 2003 Dipterocarpaceae; In: The families and genera of vascular plants $V$ : Flowering plant-DicotyledonsMalvales, Capparales and Non-betalain Caryophyllales, (eds) Kubitzki K and Bayer C (Berlin, Heidelberg, New York: Springer), pp. 182-197.

Awasthi N 1992 Changing patterns of vegetation through Siwalik succession; Palaeobotanist 40 312-327.

Awasthi N 1994 Dipterocarpus in the Indian subcontinent: Past, present and future; In: Proceedings of fifth round-table conference on Dipterocarpus, Chiang Mai (Thailand), pp. 138-156.

Bande M B 1992 The Palaeogene vegetation of peninsular India (megafossil evidence); Palaeobotanist 40 275-284.

Biswas S K and Raju D S N 1973 The rock stratigraphic classification of Tertiary sediments of Kutch; Bull. Oil Nat. Gas Commn. 10(1-2) 37-45.

Bossuyt F and Milinkovitch M C 2001 Amphibians as indicators of early Tertiary 'out-of-India' dispersal of vertebrates; Science 292 93-95.

Champion H G and Seth S K 1968 A revised survey of the forest types of India (Delhi: Manager of Publications).

Chowdhury K A and Ghosh S S 1958 Indian Woods I (Delhi: Manager of Publications).

Conti E, Eriksson T, Schönenberger J, Sytsma K J and Baum D A 2002 Early Tertiary out-of-India dispersal of Crypteroniaceae: Evidence from phylogeny and molecular dating; Evolution 56(10) 1931-1942. 
Dilcher D L 1974 Approaches to the identification of angiosperm leaf remains; Bot. Rev. 40(1) 1-157.

Dutta S, Tripathi S M, Mallik M, Mathews R P, Greenwood P F, Malagalapalli R R and Summons E 2011 Eocene outof-India dispersal of Asian dipterocarps; Rev. Palaeobot. Palynol. 166 63-68.

Foxworthy F W 1946 Distribution of the Dipterocarpaceae; J. Arnold Arboretum. 27(4) 347-354.

Guleria J S 1992 Neogene vegetation of peninsular India; Palaeobotanist 40 285-311.

Guleria J S, Srivastava R and Prasad M 2000 Some fossil leaves from the Kasauli Formation of Himachal Pradesh, North-west India; Himalayan Geol. 21 43-52.

Hickey L J 1973 Classification of the architecture of dicotyledonous leaves; Am. J. Bot. 60 17-33.

Hickey L J 1979 A revised classification of the architecture of dicotyledonous leaves; In: Anatomy of the Dicotyledons (eds) Metcalfe C R and Chalk L (Oxford: Clarenden Press), pp. 25-39.

Khan M A and Bera S 2010 Record of fossil fruit wing of Shorea Roxb. from the Neogene of Arunachal Pradesh; Curr. Sci. 98(12) 1573-1574.

Lakhanpal R N 1970 Tertiary floras of India and their bearing on the historical geology of the region; Taxon 19(5) 675-694.

Lakhanpal R N 1974 Geological history of the Dipterocarpaceae; In: Symposium on origin and phytogegraphy of angiosperms (ed.) Lakhanpal R N (Lucknow: Birbal Sahni Institute of Palaeobotany), pp. 30-39.

Lakhanpal R N and Guleria J S 1982 Plant remains from the Miocene of Kachchh, western India; Palaeobotanist 30(3) 279-296.

Lakhanpal R N, Guleria J S and Awasthi N 1984 The fossil floras of Kachchh III Tertiary megafossils; Palaeobotanist 33 228-319.

Leaf Architecture Working Group 1999 Manual of leaf architecture - morphological description and categorization of dicotyledonous and net-veined monocotyledonous angiosperms (Washington DC: Smithsonian Institution).

Mabberley D J 1997 The Plant Book II. A Portable Dictionary of Vascular Plants (Cambridge: Cambridge University Press).
Mehrotra R C 2003 Status of plant megafossils during the Early Paleogene in India; In: Causes and Consequenses of Globally Warm Climates in the Early Paleogene (eds) Wing S L, Gingetich P D, Schmitz B and Thomas E (Boulder, Colorado: Geological Society of America Special Paper), pp. 423-423.

Mehrotra R C, Liu Xiu-Qun, Li Chen-Sen, Wang Yu-Fei and Chauhan M S 2005 Comparison of the Tertiary flora of southwest China and northeast India and its significance in the antiquity of the modern Himalaya flora; Rev. Palaeobot. Palynol. 135 145-163.

Pearson R S and Brown H P 1932 Commercial timbers of India 1 \& 2 (Calcutta: Government of India Central Publication).

Prasad M 2006 Siwalik plant fossils from the Himalayan foothills of Himachal Pradesh, India and their segnificance on palaeoclimate; Phytomorphology 56(1\&2) 9-22.

Ridley H N 1922 The flora of the Malay Peninsula-I; (London: Reeve and Co. Ltd.)

Rutschmann F, Eriksson T, Schönenberger J and Conti E 2004 Did Crypteroniaceae really disperse out of India? Molecular dating evidence from rbcL, ndhF, and rpl16 intron sequences; Int. J. Plant Sci. 165(4) S69-S83.

Santapau H and Henry A N 1973 A dictionary of the flowering plants in India (New Delhi: Publication and Information Directorate, CSIR New Delhi).

Sasaki S 2006 Ecology and physiology of Dipterocarpaceae; In: Plantation Technology in Tropical Forest Science (eds) Suzuki K, Ishii K, Sakurai S and Sasaki S (Tokyo: Springer), pp. 3-22.

Shi G and Li H 2010 A fossil fruit wing of Dipterocarpus from the middle Miocene of Fujian, China and its palaeoclimatic significance; Rev. Palaeobot. Palynol. 162 599-606.

Smith A G, Smith D G and Funnell B M 1994 Atlas of Mesozoic and Cenozoic Coastlines (Great Britain: Cambridge University Press).

Srivastava G and Mehrotra R C 2010 Tertiary flora of northeast India vis-à-vis movement of the Indian plate; Geol. Soc. India Memoir 75 123-130.

Willis J C 1973 A dictionary of flowering plants and ferns; (Cambridge: Cambridge University Press). 